\title{
PENERAPAN PENDEKATAN SAINTIFIK DALAM MENINGKATKAN KEMAMPUAN SISWA MENULIS TEKS IKLAN KELAS VIII.2 MTS NEGERI 1 KONAWE
}

\author{
Ihsan Zulhiad ${ }^{1}$, Hilaluddin Hanafi ${ }^{2}$, Aris Badara ${ }^{3}$ \\ 1,2,3 Universitas Halu Oleo
}

Email : ihsamzulhiad@gmail.com

\begin{abstract}
Abstrak: Penelitian ini bertujuan (1) Untuk mengetahui bagaimana Penerapan Pendekatan Saintifik dalam Pembelajaran Menulis Teks Iklan Pada Siswa Kelas VIII.2 MTs Negeri 1 Konawe; (2) Untuk mengetahui hasil Penerapan Pendekatan Saintifik dalam Pembelajaran Menulis Teks Iklan Pada Siswa Kelas VIII.2 MTs Negeri 1 Konawe. Penelitian ini menggunakan jenis penelitian kualitatif. Hasil penelitian dapat disimpulkan (1) Penerapan pendekatan saintifik dalam pembelajaran menulis teks iklan dilakukan dengan menggunakan langkah-langkah yang ada dalam pendekatan saintifik.; (2) Penerapan langkah-langkah saintifik dalam pembelajaran menulis teks iklan yang dilakukan pendidik menghasilkan karya yang baik. Tulisan yang dihasilkan setiap individu berbeda, karena pada dasarnya kemampuan berpikir setiap peserta didik juga berbeda. Kerja kelompok yang dilaksanakan peserta didik menghasilkan tulisan berupa teks iklan yang kompleks, sehingga keberagaman yang ada menjadi satu kesatuan yang utuh dan bervariasi.
\end{abstract}

Kata Kunci: Pembelajaran Bahasa Indonesia; Saintifik; Teks Iklan 


\section{Pendahuluan}

Pendidikan pada umumnya merupakan suatu kegiatan yang dilakukan oleh seorang individu untuk mendapatkan suatu pengetahuan yang diharapkan berkualitas baik melalui pendidikan formal maupun nonformal. Pendidikan non formal biasanya terjadi di dalam lingkungan masyarakat saat seseorang individu melakukan interaksi sosial seperti saling membantu satu sama lain dan biasanya juga terjadi di dalam lingkungan keluarga. Tetapi, yang paling mendominasi pelaksanaan pendidikan adalah pendidikan formal baik mulai dari jenjang SD, SMP, SMA sampai pada tahap perguruan tinggi. Pendidikan bertujuan untuk memberikan suatu bekal pengetahuan kepada peserta didik, yang dimana pengetahuan tersebut dapat digunakan untuk memecahkan segala jenis permasalahan yang dialami oleh peserta didik dan juga bisa digunakan sebagai daya saing di kemudian hari.

Setiap saat, pemerintah selalu senantiasa meningkatkan kualitas pendidikan agar kualitas pengetahuan peserta didik turut meningkat pula. Peningkatan kualitas pendidikan yang dilakukan oleh pemerintah dilakukan dengan cara memberikan pembelajaran tambahan kepada pendidik beserta teknik-teknik pengajaran yang lebih baik lagi. Upaya peningkatan kualitas pendidikan yang dilakukan oleh pemeritah yang sangat nampak adalah perubahan kurikulum sampai pada Kurikulum 2013 yang digunakan saat ini. Perubahan kurikulum tersebut bertujuan agar kualitas pendidikan peserta didik meningkat. Saat pertamakali penerapan kurikulum K-13, banyak sekolah yang menolak karena proses penilaian pembelajaran dan materi pelajaran yang dianggap sulit. Tetapi seiring berjalannya waktu, K-13 dapat terealisasi dengan baik di lingkungan pendidikan MTs Negeri 1 Konawe khususnya.

Pada hakekatnya, poses belajar mengajar merupakan proses interaksi atau hubungan timbal balik antara guru dan siswa dalam suatu pembelajaran. Guru merupakan komponen penting dalam proses belajar mengajar. Guru bukan hanya sebagai penyampai materi seja, tetapi lebih dari itu, guru dapat dikataka sebagai sentral pembelajaran. Guru mengemban tugas yang berat untuk tercapainya tujuan pendidikan nasional yaitu meningkatkan kualitas manusia Indonesia, manusia yang seutuhnya beriman dan bertaka kepada tuhan yang maha esa berbudi pekerti, disiplin, bekerja keras dan bertanggung jawab. Sejalan dengan iitu, pendidikan nasional akan mampu mewujudkan manusia yang bertanggung jawab atas pembangunan bangsa (Depdikbud, 1999:26).

Dalam dunia pendidikan, seorang pendidik dituntut harus mencerdaskan kehidupan bangsa dimulai dari menciptakan suatu pembelajaran yang berkualitas agar tercipa suatu generasi penerus yang mempunyai bekal pengetahuan yang berkualitas. Pemerintah senantiasa meningkatkan keterampilan guru dalam proses pengajaran melalui pelatihan di setiap wilayah. Tetapi, pelatihan tersebut belum mampu menyetarakan seluruh kemampuan guru dalam proses pengajaran dikarenakan penyelenggaraan kegiatan pelatihan guru yang tidak menyeluruh.

\begin{tabular}{llr}
\multicolumn{1}{c}{ Dalam } & \multicolumn{2}{c}{ proses pembelajaran } \\
terutama & pembelajaran & bahasa \\
Indonesia, & ada beberapa aspek
\end{tabular} kebahasaan yang perlu diperhatikan diantaranya adalah aspek menulis. Menulis adalah kegiataan menurunkan, menirukan atau melukiskan lambang grafik yang menggambarkan suatu bahasa yang dipahami oleh seseorang, sehingga orang lain tersebut dapat 
membaca lembang grafik tersebut. Secara geris besar, menulis merupakan keterampilan berbahasa yang dimiliki dan digunakan manusia sebagai alat komunikasi secara tidak langsung yang memiliki tahapan dalam proses penulisannya dan menjadikan seseorang mendapatkan kesuksesan dalam membuat tulisan, proses melukiskan lambang-lambang yang dapat dipahami dan melahirkan pikiran atau gagasan dengan menggunakan bahasa secara ekspresif berdasarkan kreativitas.

Menulis merupakan suatu kegiatan yang terpenting di dalam hidup menusia. Dengan menulis, setiap individu dapat meluapkan ide, gagasan dan fikirannya kepada khalayak dan bahkan tidak jarang banyak individu yang menjadikan menulis menjadi sumber mata pencahrian seperti menjadi penulis buku dan lain sebahagainya, karena pada hakekatnya menulis merupakan suatu kegiatan untuk menyiptakan suatu catatan atau informasi pada suatu media dengan menggunakan aksara.

Dalam dunia pendidikan, menulis merupakan suatu hal yang wajib dikuasai oleh pelajar, karena menulis merupakan salah satu tolak ukur untuk mengetahui kemampuan pelajar. Tetapi, masih banyak siswa yang belum menguasai teknik penulisan yang baik dan benar, mereka hanya menulis sesuka hati tanpa memerhatikan aturan penulisan yang baik dan benar dan mengikuti struktur dan kaidah kebahasaan hal yang akan ditulisnya.

Di salah satu institusi pendidikan di kabupaten konawe yaitu di MTs Negeri 1 Konawe, peneliti melihat ada suatu masalah yang dialami oleh siswa siswi yaitu dalam hal menulis teks teks iklan, dimana dalam materi penulisan teks iklan ini, banyak siswa yang mengalami kesulitan saat akan menulis teks iklan sesuai struktur dan unsur kebahasaan. Dalam materi teks iklan, siswa diarahkan untuk menulis suatu iklan penjualan produk maupun jasa maupun layanan masyarakat yang sesuai dengan struktur dan unsur kebahasaan teks iklan. Tetapi, menurut salah satu guru yang mengajar di kelas VIII.2, masih banyak siswa yang masih kurang memahami teknik penulisan teks iklan yang baik dan banar.

Dalam kurikulum 2013, telah dijelaskan mengenai pendekatan saintifik yang dimana pendekatan pembelajaran ini berfokus kepada siswa sebagai sumber belajar, dimana siswa yang diharapkan lebih aktif dibandingkan guru, tetapi arahan dari pemerintah masih belum di laksanakan dengan maksimal oleh kebanyakan pengajar.

Pendekatan saintifik adalah salah satu komponen penting dari kurikulum 2013. Namun, para guru di semua tingkatan pendidikan masih mengalami kesulitan dalam menerapkan pendekatan ini. Lebih buruk lagi, pemerintah kita di tingkat lokal dan nasional belum dapat menyebarluaskan pendekatan ilmiah secara sistematis. Seorang guru mengalami masalah yang sangat serius dalam menerapkan pendekatan saintifik di ruang kelas. Diindikasikan oleh temuan bahwa: (a) mengajar masih berpusat pada guru, (b) pembelajaran satu arah berlaku, (c) tidak ada pemanfaatan jaringan, (d) siswa tidak didorong untuk secara aktif melakukan pengamatan, (e) fokus pembelajaran adalah pada dunia maya, (f) pengetahuan terlalu umum dan sebagian besar tidak dapat diterapkan dalam kehidupan nyata (Aris Badara dan Hilaluddin Hanafi, 2017).

Keuntungan dari pendekatan yang diperoleh oleh penelitian ini sejalan dengan apa yang telah diungkapkan oleh A. Machin (2014:28-35), yang menunjukkan bahwa pendekatan ilmiah dapat: (a) meningkatkan keterampilan 
intelektual, (b) membangun siswa ' keterampilan memecahkan masalah, (c) membuat siswa menganggap pembelajaran mereka sebagai suatu kebutuhan, (d) mempromosikan hasil belajar yang baik, (e) melatih siswa cara berkomunikasi dengan alien, dan (f) karakter pribadi yang tidak dapat dipelajari.

Temuan penelitian ini menunjukkan bahwa walaupun para guru melakukan pendekatan saintifik, mereka melakukannya tanpa mengikuti prosedur pendekatan tersebut. Misalnya, mereka tidak menggunakan metode pengajaran apa pun yang terkait dengan pendekatan tersebut, seperti pembelajaran berbasis masalah, pembelajaran berbasis proyek, atau pembelajaran discovery. Selain itu, pendekatan saintifik juga harus dipandu oleh prinsip-prinsip ilmiah. Pendekatan ini ditandai dengan penekanannya pada dimensi pengamatan, asosiasi, penemuan, validasi, dan penjelasan kebenaran. Karena itu, semua proses pembelajaran harus mematuhi nilai-nilai ilmiah, prinsip, atau kriteria. Temuan penelitian ini menunjukkan bahwa beberapa komponen dari pendekatan ilmiah yang diterapkan oleh para guru perlu diperkuat, karena hal-hal berikut.

Beberapa guru masih tidak dapat menginspirasi dan mendorong siswa mereka untuk berpikir kritis, analitis, dan benar ketika mengidentifikasi, memahami, dan memecahkan masalah, serta ketika menerapkan substansi bahan yang mereka pelajari. Dalam banyak kesempatan, para guru masih tidak dapat mendorong dan menginspirasi siswa mereka untuk berpikir secara kritis. Para guru juga tidak dapat menginspirasi siswa mereka, menyebabkan mereka tidak dapat memahami, menerapkan, dan mengembangkan pola pikir yang rasional dan objektif (Badara dan Hanafi, 2017).
Berdasarkan uraian di atas, maka peneliti melakukan penelitian dengan judul "Penerapan Pendekatan Saintifik dalam Pembelajaran Menulis Teks Iklan Pada Siswa Kelas VIII.2 Mts Negeri 1 Konawe".

\section{Hakikat Pembelajaran}

Menurut Sagala

(2009:61)

Pembelajaran adalah "membelajarkan siswa menggunakan asas pendidikan maupun teori belajar yang merupakan penentu utama keberhasilan pendidikan". Pembelajaran merupakan proses komunikasi dua arah. Mengajar dilakukan pihak guru sebagai pendidik., sedangkan belajar oleh peserta didik. Menurut Corey pembelajaran adalah suatu proses dimana lingkungan seeorang secara disengaja dikelola untuk memungkinkan ia turut serta dalam tingkah laku dalam kondisi khusus atau menghasilkan respon terhadap situasi tertentu.

Undang-Undang Sistem Pendidikan Nasional No. 20 Tahun 2003. Pembelajaran adalah "proses interaksi peserta didik dengan pendidik dan sumber belajar pada suatu lingkungan belajar". Pembelajaran sebagai proses belajar yang dibangun oleh guru untuk mengembangkan kreatifitas berpikir yang dapat meningkatkan kemampuan berpikir siswa, serta dapat meningkatkan kemampuan mengkontruksikan pengetahuan baru sebagai upaya meningkatkan penguasaan yang baik terhadap materi pelajaran.

Menurut Hamalik (2006:239) Pembelajaran adalah "suatu kombinasi yang tersusun meliputi unsur-unsur manusiawi, material fasilitas, perlengkapan dan prosedur yang saling mempengaruhi tercapainya tujuan pembelajaran".

\section{Hakikat Pendekatan Pembelajaran}

Pendekatan pembelajaran dapat diartikan sebagai titik tolak atau sudut 
pandang kita terhadap proses pembelajaran, yang merujuk pada pandangan tentang terjadinya suatu proses yang sifatnya masih sangat umum, di dalamnya mewadahi, menginsiprasi, menguatkan, dan melatari metode pembelajaran dengan cakupan teoretis tertentu. Dilihat dari pendekatannya, pembelajaran terdapat dua jenis pendekatan, yaitu: (1) pendekatan pembelajaran yang berorientasi atau berpusat pada siswa (student centered approach) dan (2) pendekatan pembelajaran yang berorientasi atau berpusat pada guru (teacher centered approach). Teori Metode Pembelajaran. Selain itu, menurut Depdikbud (1990: 180) pendekatan dapat diartikan, "sebagai proses, perbuatan, atau cara untuk mendekati sesuatu". Wahjoedi (1999:121) menjelaskan bahwa, "pendekatan pembelajaran adalah cara mengelola kegiatan belajar dan perilaku siswa agar ia dapat aktif melakukan tugas belajar sehingga dapat memperoleh hasil belajar secara optimal".

Sagala (2005: 68) Pendekatan pembelajaran merupakan jalan yang akan ditcmpuh oleh guru dan siswa dalam mencapai tujuan instruksional untuk suatu satuan instruksional tertentu. Selain itu, Sanjaya (2008:127) menegaskan pendekatan pembelajaran yang berpusat pada siswa menurunkan strategi pembelajaran discovery dan inkuiri serta strategi pembelajaran induktif. Selain itu, Suherman (1993:220) mengemukakan pendekatan dalam pembelajaran adalah suatu jalan, cara atau kebijaksanaan yang ditempuh oleh guru atau siswa dalam pencapaian tujuan pembelajaran dilihat dari sudut bagaimana proses pembelajaran atau materi pembelajaran itu, umum atau khusus.

\section{Hakikat Pendekatan Saintifik}

Pendekatan saintifik adalah proses pembelajaran yang dirancang sedemikian rupa agar peserta didik secara aktif mengkonstruk konsep, hukum dan prinsip melalui tahapan tahapan mengamati (untuk mengidentifikasi atau menemukan masalah), merumuskan masalah, mengajukan atau merumuskan hipotesis, mengumpulkan data dengan berbagai teknik, menganalisa data, menarik kesimpulan dan mengkomunikasikan konsep, hukum atau prinsip yang "ditemukan" (Hosnan,2014:34). Dalam pembelajaran saintifik diharapkan tercipta kondisi pembelajaran yang mendorong peserta didik untuk mencari tahu informasi dari berbagai sumber melalui observasi, dan bukan hanya diberi tahu.

Pembelajaran yang melibatkan pendekatan saintifik akan melibatkan keterampilan proses, seperti kegiatan pengamatan atau observasi yang dibutuhkan untuk pengajuan hipotesis atau pengumpulan data. Menurut Sani (2014: 51) metode ilmiah pada umumnya dilandasi dengan pemaparan data yang diperoleh melalui pengamatan atau percobaan. Oleh sebab itu, percobaan dapat diganti dengan kegiatan memperoleh informasi dari berbagai sumber. Dalam melakukan kegiatan tersebut, bantuan atau bimbingan guru tetap dibutuhkan.

\section{Hakikat Menulis}

Djuharie (2005: 120) Menulis merupakan suatu keterampilan yang dapat dibina dan dilatih. Selain itu, Ebo (2005:1) Menulis itu dapat dilakukan oleh setiap orang dengan cara dibina dan dilatih. Diisamping itu, Pranoto (2004; 9) Menulis berarti menuangkan buah pikiran kedalam bentuk tulisan atau menceritakan sesuatu kepada orang lain melalui tulisan. Menulis juga dapat diartikan sebagai ungkapan atau ekspresi 
perasaan yang dituangkan dalam bentuk tulisan. Dengan kata lain, melalui proses menulis kita dapat berkomunikasi secara tidak langsung.

Gebhardt dan Dawn Rodrigues (1989:1) Writing is one of the most important things you do in college. Menulis merupakan salah satu hal paling penting yang kamu lakukan di sekolah. Disamping itu, Djago Tarigan dalam Elina Syarif, Zulkarnaini, Sumarno (2009:5) Menulis berarti mengekpresikan secara tertulis gagasan, ide, pendapat, atau pikiran dan perasaan. Lado dalam Elina Syarif, Zulkarnaini, Sumarno (2009:5) juga mengungkapkan pendapatnya mengenai menulis yaitu: meletakkan simbol grafis yang mewakili bahasa yang dimengerti orang lain. Heaton dalam St. Y. Slamet (2008:141) berpendapat bahwa Menulis merupakan keterampilan yang sukar dan kompleks.

Tarigan (1986:15) Menyatakan bahwa menulis dapat diartikan sebagai kegiatan menuangkan ide/gagasan dengan menggunakan bahasa tulis sebagai media penyampai. Selain itu, Barli Bram (2002:7) In principle, to write means to try to produce or reproduce writen message. Barli Bram mengartikan menulis sebagai suatu usaha untuk membuat atau mereka ulang tulisan yang sudah ada.

Eric Gould, Robert DiYanni, dan William Smith (1989:18) menyebutkan writing is a creative act, the act of writing is creative because its requires to interpret or make sense of something: a experience, a text, an event. Menulis adalah perilaku kreatif, perilaku menulis kreatif karena membutuhkan pemahaman atau merasakan sesuatu: sebuah pengalaman, tulisan, peristiwa.

Semi (2007:14) juga berpendapat bahwa Menulis adalah suatu proses kreatif memindahkan gagasan ke dalam lambang-lambang tulisan. Selain itu, Burhan.Nurgiantoro

(1988:273)
Menyatakan bahwa menulis adalah aktivitas aktif produktif, yaitu aktivitas menghasilkan bahasa. Selain itu, McCrimmon dalam St. Y. Slamet (2008:141) menulis merupakan kegiatan menggali pikiran dan perasaan mengenai suatu subjek, memilih hal-hal yang akan ditulis, menentukan cara menuliskannya sehingga pembaca dapat memahaminya dengan mudah dan jelas. Slamet (2008:72) sendiri mengemukakan pendapatnya tentang menulis yaitu kegiatan yang memerlukan kemampuan yang bersifat kompleks.

Angelo (1980:5) menulis adalah suatu bentuk berpikir, tetapi justru berpikir bagi membaca tertentu dan bagi waktu tertentu. Salah satu tugas terpenting sang penulis adalah menguasai prinsip-prinsip menulis dan berpikir, yang akan dapat menolongnya mencapai maksud dan tujuannya. Yang paling penting di antara prinsip-prinsip yang dimaksudkan itu adalah penemuan, susunan, dan gaya. Secara singkat belajar menulis adalah belajar berpikir dalam/dengan cara tertentu.

Dari beberapa pengertian menulis di atas, penunis lebih merujuk pada pendapat Burhan Nurgiantoro yang menyatakan bahwa menulis adalah aktivitas aktif produktif, yaitu aktivitas menghasilkan bahasa.

\section{Hakikat Teks Deskripsi}

Menurut KBBI, arti teks deskripsi adalah suatu pemaparan, uraian atau penggambaran dengan kata-kata secara jelas dan terperinci. Selain itu, menurut HenryGuntur Tarigan (1994), Pengertian teks deskripsi adalah tulisan yang bisa melukiskan sebuah kisah yang bertujuan untuk mengajak pembaca agar bisa memahami, merasakan dan menikmati objek yang dibicarakan seperti suasana hati, aktivitas dan sebagainya. Pendapat lain dikemukakan oleh Keraf (1982:93), mengartikan teks deskripsi adalah suatu wacana yang digunakan untuk 
menyampaikan hal atau objek pembicaraan sehingga para pembaca seperti melihat sendiri objek tersebut secara langsung. Di dalam deskripsi penulis memindahkan kesan-kesannya, hasil pengambaran, perasaan, penyampaian sifat, dan rincian wujud yang ditemukan pada objek.

Berdasarkan beberapa pendapat di atas, penulis menarik kesimpulan bahwa teks deskripsi adalah suatu tulisan yang bertujuan untuk menggambarkan bentuk objek pengamatan, sifatnya, rasanya, atau coraknya dengan mengandalkan pancaindra dalam proses penguraiannya.

\section{Pengertian Iklan}

Kamus Besar Bahasa Indonesia (KBBI) menjelaskan iklan adalah berita atau pesan untuk mendorong, membujuk khalayak ramai agar tertarik pada barang dan jasa yang ditawarkan; pemberitahuan kepada khalayak mengenai barang atau jasa yang dijual, dipasang di dalam media massa (seperti surat kabar dan majalah) atau di tempat umum.Wikipedia menjelaskan Iklan atau pariwara merupakan promosi benda seperti barang, jasa, tempat usaha atau ide yang harus dibayar oleh sponsor.Dalam dunia manajemen pemasaran, iklan merupakan salah satu dari strategi promosi secara global atau keseluruhan.

Kriyantono

Mengemukakan bahwa iklan merupakan bentuk komunikasi non-personal yang menjual pesan-pesan secara persuasif dari sponsor yang jelas guna untuk mempengaruhi orang agar membeli produk dengan membayar biaya untuk media yang digunakan. Selain itu, Durianto (2003) Mendefinisikan iklan sebagai proses komunikasi yang tujuannya untuk membujuk atau menggiring orang agar mengambil tindakan yang menguntungkan bagi pihak pembuat iklan.
Suhandang

(2005:7)

mengemukakan iklan sebagai salah satu jenis teknik komunikasi massa dengan membayar ruangan atau waktu untuk menyiarkan informasi tentang barang dan jasa yang ditawarkan oleh si pemasang iklan. Gilson \& Berkman (1980:40) menurut mereka, iklan adalah media komunikasi persuasif yang dirancang sedemikian rupa untuk menghasilkan respon dan membantu tercapainya objektifitas atau tujuan pemasaran. Disamping itu, Russel \& Lane (1990:12) Mereka berpendapat bahwa iklan ialah suatu pesan yang dibayar oleh sponsor dan disampaikan melalui beberapa media komunikasi massa.

Wright (1978:3) Beliau berpendapat tentang iklan bahwa: iklan merupakan sebuah proses komunikasi yang memiliki kekuatan yang sangat penting sebagai alat pemasaran yang sangat membantu dalam menjual barang, memberikan layanan dan gagasan melalui saluran tertentu dalam bentuk informasi persuasif. Pendapat serupa dikemukakan oleh Wells (1992:5) Mengemukakan bahwa iklan merupakan salah satu bentuk komunikasi nonpersonal yang dibayar oleh pihak sponsor dengan menggunakan media massa dan bertujuan untuk membujuk dan mempengaruhi audience (penonton, pendengar atau pembaca).

\section{Metode Penelitian}

Penelitian ini akan dilaksanakan di salah satu sekolah madrasah di Kabupaten Konawe dan adapun nama sekolahnya yaitu MTs N 1 Konawe. Adapun waktu penelian yang ditarget oleh peneliti yaitu pada bulan 1 semester genap tahun pelajaran 2019/2020, dan waktu yang akan digunnakan oleh peneliti untuk mengamati pendekatan saintifik kurang lebih selama 7 kali tatap muka atau $21 \mathrm{JP}$. Yaitu penelitian yang 
bertujuan utama untuk menganalisis penerapan pendekatan saintifik dalam pembelajaran menulis iklan pada siswa kelas VIII.2 MTs neferi 1 konawe.

Penelitian ini menggunakan tiga macam sumber data, yaitu: dokumen, wawancara, dan hasil observasi merupakan data utama yang diperoleh. Sumber data dari lapangan yang menjadi sumber data primer terdapat informan kunci yang ditemukan dilapangan yaitu HR sebagai pendidik mata pelajaran Bahasa Indonesia di kelas VIII.2. Sumber data dokumen berupa hardcopy maupun softcopy merupakan data utama. Data dari hasil observasi merupakan data yang menjadi penguat data berupa dokumen dan wawancara. Sumber data berupa subjek dalam penelitian ini terdiri dari pendidik bidang studi Bahasa Indonesia dan para peserta didik guna untuk mengetahui kreativitas dan inovatif pendidik mata pelajaran Bahasa Indonesia dalam menerapkan pendekatan saintifik dalam proses pembelajaran.

\section{Hasil Penelitian dan Pembahasan}

Dari hasil penerapan pendekatan saintifik dalam pembelajran menulis teks iklan pada siswa kelas VIII.2 Mts Negeri 1 Konawe. Deskripsi meliputi perencanaan pembelajaran dalam menerapkan pendekatan scientific, pelaksanaan penerapan pendekatan scientific dalam pembelajaran menulis teks iklan, hasil penerapan pendekatan scientific dalam pembelajaran menulis teks iklan, temuan penelitian, langkahlangkah penerapan pendekatan saintifik dalam pembelajaran menulis iklan kelas VIII.2 MTs Negeri 1 Konawe dan kemampuan peserta didik dalam menulis teks iklan menggunakan pendekatan saintifik di kelas VIII.2 MTs Negeri 1 Konawe. hasil penelitian dan pembahasan merupakan hasil analisis data yang diperoleh selama penelitian.
Data diperoleh dari hasil observasi dan wawancara.

\section{Perencanaan Pembelajaran dalam Menerapkan Pendekatan Scientific}

Mengacu pada Kurikulum 2013, pendidik merupakan fasilitator dalam pembelajaran. Penerapan pendekatan yang dilakukan oleh pendidik dalam pembelajaran Bahasa Indonesia di kelas VIII.2. HR selaku pendidik mengaku menerapkan pendekatan tersebut dalam pembelajaran teks iklan. Sebelum pendidik menerapkan pembelajaran sesuai langkah-langkah yang sudah ditentukan dalam pendekatan saintifik $\mathrm{K} 13$, beliau merancang pembelajaran terlebih dahulu.

\section{Pelaksanaan Penerapan Pendekatan Scientific dalam Pembelajaran Menulis Teks Iklan \\ Dari pernyataan HR tersebut} membuktikan bahwa penerapan langkah- langkah dalam pendekatan saintifik membutuhkan dasar yang jelas. RPP disusun dengan KD dan indikator yang sesuai dengan tujuan pendekatan saintifik. Kegiatan dalam langkahlangkah penerapan pendekatan saintifik juga dirancang dengan sedemikian rupa untuk proses pembelajaran. HR juga menyebutkan bahwa langkah-langkah penerapan pendekatan saintifik ada 5 dan dimulai dengan urut, yaitu dimulai dari mengamati, menanya, menalar, mencoba, mengomunikasikaan. Langkah-langkah penerapan pendekatan saintifik tersebut sudah disusun dengan runtun di dalam RPP.

\section{Hasil Penerapan Pendekatan \\ Scientific dalam Pembelajaran Menulis Teks Iklan}

Dimulai dari menyusun rancangan pembelajaran sebelum proses pembelajaran dimulai. Pendidik juga harus memperhatikan penerapan pendekatan saintifik melalui langkahlangkah yang sudah ditetapkan. Yang 
terakhir adalah hasil dari menulis teks iklan yang dilakukan peserta didik secara berkelompok. Data yang diperoleh peneliti dari hasil pengumpulan data yang telah peneliti lakukan. Peneliti menemukan hasil tulisan berupa teks iklan yang dikerjakan peserta didik secara berkelompok dan sudah di presentasikan.

Dari hasil teks iklan yang diperoleh oleh peneliti, ada beberapa hal penjelasan dari HR mengenai hasil yang berbeda. Sesuai dengan yang dijelaskan HR bahwa peserta didik mempunyai kondisi individual yang berbeda-beda, maka hasil dari tulisannyapun juga berbeda-beda. Dalam penilaian yang dilakukan HR.

\section{Temuan Penelitian}

Berdasarkan paparan data yang peneliti peroleh dari hasil pengumpulan data dari wawancara, dokumen dan observasi, peneliti menemukan temuantemuan berupa data yang konkrit. Peneliti menemukan rencana pembelajaran telah direncanakan sebelumnya oleh pendidik yaitu berupa RPP beserta aspek penilaiannya. Perencanaan yang dilakukan HR tidak cukup dalam penulisan RPP akan tetapi HR juga merusmuskan bersama guruguru lain yang serumpun, sehingga perencanaan yang dilakukan menjadi terstruktur dengan guru-guru yang serumpun.

Peneliti juga menemukan bahwa penerapan dalam pembelajaran yang dilakukan HR sudah melaksanakan langkah-langkah pendekatan saintifik yang dimulai dari kegiatan peserta didik mengamati teks ekplanasi, kemudian dilanjut dengan kegiatan menanya sebagai tindak lanjut dari hasil mengamati, setelah memahami dan mendapatkan apa yang mereka cari kemudian dilanjut kegiatan mencoba, setelah kegiatan mencoba kemudian dilanjut dengan kegiatan menalar dan diakhiri dengan kegiatan mengomunikasikan sebagai langkah terakhir. Dari hasil penerapan langkahlangkah tersebut, peserta didik berhasil menuliskan berupa teks iklan yang terdapat struktur, kaidah kebahasaan, serta ciri-ciri teks eksplanasi.

\section{Langkah-Langkah Penerapan Pendekatan Saintifik dalam Pembelajaran Menulis Iklan Kelas VIII.2 MTs Negeri 1 Konawe}

Pendekatan ilmiah (Scientific) telah diterapkan pada peserta didik kelas VIII.2 MTs Negeri 1 Konawe oleh HR selaku guru Bahasa Indonesia. HR malaksanakan perencanaan terlebih dahulu dengan guru yang serumpun di MTs Negeri 1 Konawe. Selain melaksanakan musyawarah dengan guru yang serumpun, HR juga mencocokkan rencana pembelajaran dengan guru-guru selain dari MTs Negeri 1 Konawe.

Langkah-langkah

dalam penerapan pendekatan sainftifik juga telah dilakukan secara tersusun dalam proses pembelajaran. Sesuai data yang peneliti peroleh, penerapan pendekatan yang dilakukan oleh HR telah sesuai dengan langkah-langkah yang tentunya harus diterapkan guna memaksimalkan pembelajaran dalam K13.

Kemampuan Peserta Didik dalam Menulis Teks Iklan Menggunakan Pendekatan Saintifik di Kelas VIII.2 MTs Negeri 1 Konawe

Sesuai data yang didapat oleh peneliti dilapangan, keadaan peserta didik disetiap individu memang berbeda. Dari kondisi yang berbeda tersebut, hasil tulisan dari setiap individupun juga berbeda. Dalam penilaian yang dilakukan HR terhadap hasil kerja peserta didik digolongkan menjadi tiga bagian yaitu yang cukup baik, baik, sangat baik. HR sendiri menggolongkan hal tersebut sesuai dengan kemampuan peserta didik yang mempunyai kemampuan berbeda-beda. Menurut HR 
hal yang bisa memberikan spesifikasi cukup baik, baik, sangat baik itu ada didalam penilaian setelah pembelajaran selesai.

\section{Penutup}

Berdasarkan hasil penelitian yang telah dilakukan dilapangan dan hasil analisis serta hasil pembahasan tentang penerapan pendekatan scientific dalam pembelajaran menulis teks iklan pada siswa kelas VIII.2 MTs Negeri 1 Konawe, maka penelitian ini dapat disimpulkan sebagai berikut:

1. Penerapan pendekatan saintifik dalam pembelajaran menulis teks iklan dilakukan dengan menggunakan langkah-langkah yang ada dalam pendekatan saintifik. Peserta didik mengamati materi yang telah diberikan HR selaku pendidik. Kemudian dilanjut dengan menanya sebagai kegiatan aktif dari peserta didik untuk melatih daya pikir yang kritis. Dilanjutkan dengan mencoba untuk mengetahui pemahaman dari peserta didik sesuai dengan materi yang diberikan. Kemudian, menalar merupakan kegiatan yang dilakukan untuk mengetahui lebih dalam lagi struktur dan kaidah kebahasaan teks iklan beserta kutipan yang menunjukkan. Sebagai langkah terakhir adalah mengomunikasikan, sebagai salah satu cara untuk melatih mental peserta didik serta melatih peserta didik untuk berpikir lebih tinggi lagi.

2. Penerapan langkah-langkah saintifik dalam pembelajaran menulis teks iklan yang dilakukan pendidik menghasilkan karya yang baik. Tulisan yang dihasilkan setiap individu berbeda, karena pada dasarnya kemampuan berpikir setiap peserta didik juga berbeda. Pengelompokan yang dilakukan HR dalam menulis teks iklan menjadi salah satu cara untuk mengolaborasikan perbedaan peserta didik. Kerja kelompok yang dilaksanakan peserta didik menghasilkan tulisan berupa teks iklan yang kompleks, sehingga keberagaman yang ada menjadi satu kesatuan yang utuh dan bervariasi.

\section{Daftar Pustaka}

Abdullah, Sani Ridwan. 2014. Pembelajaran saintifik untuk kurikulum 2013. Jakarta: Bumi Aksara.

Badara, Aris dan Hilaluddin Hanafi.2017. A Model for Reinforcing The Implementation of Scientific Approach In Language Learning.Internasional Journal of Advanced Research.

hlm.Http://Dx.Doi.Org/10.21474/I JAR01/4260. Diakses 24/11/2019.

Daryanto. (2014). Pendekatan Pembelajaran Saintifik Kurikulum 2013. Yogyakarta: Penerbit Gava Media.

Fathurrohman, Muhammad. 2015. Paradigma Pembelajaran Kurikulum $2013 \quad$ Strategi Alternatif Pembelajaran di Era Global. Yogyakarta: Kalimedia.

Hamalik, Oemar. 2006. Proses Belajar Mengajar. Jakarta: PT. Bumi Aksara.

Hopkins. 1993. A Teacher's Guide to Classroom Research.

Philadelphia. Open University Press.

Ridwan.2002. Skala Pengukuran Variabel-Variabel Penelitian. Bandung: Alvabeta.

Sani. 2014. Pembelajaran Saintifik untuk Implementasi Kurikulum 2013. Jakarta: Bumi Aksara.

Semi, M. Atar. 2007. Dasar-Dasar Keterapilan Menulis. Bandung: Angkasa. 